\title{
Growth Response Following Fertilizer Application in the Grand'Mère Plantations
}

\section{J. D. GAGNON}

\author{
Laurentian Forest Research Centre \\ Canadian Forestry Service \\ Environment Canada \\ P.O. Box 3800, Sainte-Foy, Québec \\ G1V 4 C7
}

\section{J. M. CONWAY}

Forestry Services

Consolidated Bathurst Ltd.

Grand'Mère, Qué.

\section{H. S. D. SWAN*}

Pulp and Paper Research Institute of Canada 570 St. John's Boulevard

Pointe Claire 720, Qué.

\section{Introduction}

The Grand'Mère white spruce plantations, the oldest and largest in Canada, represent the heaviest investment of private capital to date in this type of enterprise (Conway 1964). Established in the immediate vicinity of Grand'Mère, during the period 1913-32, mostly on abandoned farm land of loamy-sand texture, they cover approximately 2,300 hectares $(6,000$ acres) of an almost level plain. The plantations are also distinguished as being the most intensively studied in Canada, as they were recognized as a problem area almost from the beginning.

As early as 1953 nutrient deficiency was the suspected cause of poor growth in a major portion of the plantations (Cunningham 1953). Subsequent studies (Conway 1960; Lafond 1958; Paine 1960; Swan 1962) indicated that potassium, and to a lesser extent nitrogen, were the elements limiting growth. Fertilizer trials by company foresters appeared to confirm this theory, which led to Consolidated-Bathurst Ltd. and the Pulp and Paper Research Institute of Canada (PPRIC) embarking on an experiment to test and determine growth response to the application of potassium and nitrogen fertilizers. The possibility that magnesium was also deficient (Lafond 1958) was provided for by incorporating this element into some of the treatments.

When the Silviculture Section at PPRIC was phased out in 1971, the desirability of maintaining all the cooperative forest fertilization field trials was recognized, and the Canadian Forestry Service

* Present address: Canadian Pulp and Paper Association, 2300 Sun Life Building, Montreal, Que.

\begin{abstract}
A study was carried out in the Grand'Mère plantations on the 10-year growth response from a fertilization trial with various levels of nitrogen and potassium. There was a growth response to potassium at the end of the experiment, while the effect of nitrogen was less apparent. The best four treatments, $\mathrm{K}_{2}, \mathrm{~N}_{2} \mathrm{~K}_{2}, \mathrm{~N}_{1} \mathrm{~K}_{1}$ and $\mathrm{K}_{1}$, produced respectively $27.8,26.9,14.7$ and 12.6 cubic meters per hectare $(4.0,3.8$, 2.1 and 1.8 cunits per acre) of extra wood.
\end{abstract}

\section{Résumé}

Cette étude fait état de 10 années de croissance suite à la fertilisation azotée et potassique ajoutée au sol des plantations de Grand'Mère. Au terme de l'expérience, l'effet du potassium sur la croissance était évident alors que celui de l'azote était moins apparent. Les quatre meilleurs traitements, $\mathrm{K}_{2}, \mathrm{~N}_{2} \mathrm{~K}_{2}, \mathrm{~N}_{1} \mathrm{~K}_{1}$ et $\mathrm{K}_{1}$, ont donné respectivement un surplus de bois de 27.8, 26.9, 14.7 et 12.6 mètres cubes par hectare $(4.0,3.8,2.1$ et 1.8 cunits par acre $)$.

agreed to assume the responsibilities previously held by PPRIC. The results of the first studies of the revised cooperative arrangement are reported in this paper.

\section{Materials and methods}

In the fall of 1962,60 square plots, 0.0404 hectares $(1 / 10$ acre) each, were established in a 35 year-old white spruce plantation in the Rang St. Mathieu area of the Grand'Mère plantations. These study plantations are representative of medium sites which occupy about $45 \%$ of the planted area (Gagnon and MacArthur 1959; Gagnon 1972).

Study areas were laid out in three blocks of 20 plots per block. Each block was split for magnesium. Thirty trees from each plot were identified and tagged at breast height. To avoid border effect, trees were chosen not less than $3.05 \mathrm{~m}$ (10 ft) from the plot perimeter. Diameters of tagged trees were measured with calipers to the nearest $0.25 \mathrm{~cm}$ ( $0.1 \mathrm{in.}$ ), and heights were taken to the nearest 2.54 $\mathrm{cm}$ (1.0 in.) with a graduated pole.

In the spring of 1963, three levels of nitrogen, three levels of potassium, and two levels of magnesium, in all combinations, were applied manually to plots. Nitrogen was added as urea $(45 \% \mathrm{~N})$ at rates of 0.57 and $114 \mathrm{~kg} / \mathrm{ha}(0,51,102 \mathrm{lb} . /$ acre $)$; potassium as sulphate of potash $\left(50 \% \quad \mathrm{~K}_{2} \mathrm{O}\right)$ at rates of 0.47 and $94 \mathrm{~kg} / \mathrm{ha}(0,42,84 \mathrm{lb}$./acre); and magnesium as magnesium sulphate at 0 and 21 $\mathrm{kg} / \mathrm{ha} \mathrm{(0}$ and $19 \mathrm{lb}$./acre) (Table 1).

Magnesium did not produce any growth response and in 1972, so magnesium was disregarded for the experiment. The experimental design became a combination of nine treatments with six replications and six extra control plots. 
The duration of the experiment having been fixed at 10 years, the last diameter measurement was made in the fall of 1972 . Only trees alive in the fall of 1972 were measured. Mortality resulted in variable numbers of trees per plot. This led to variation in basal area increment for the period 1962-72, so that diameter growth response to various fertilizers was adjusted by analysis of covariance (Table 2).

From each sample five tagged trees representative of the diameter range for the plot were felled in fall 1972. The height of the felled trees was measured for 1962 and for 1972. The former was found by counting back the appropriate number of internodes and counting the number of rings on discs taken at this point. Tree volume at the begin-

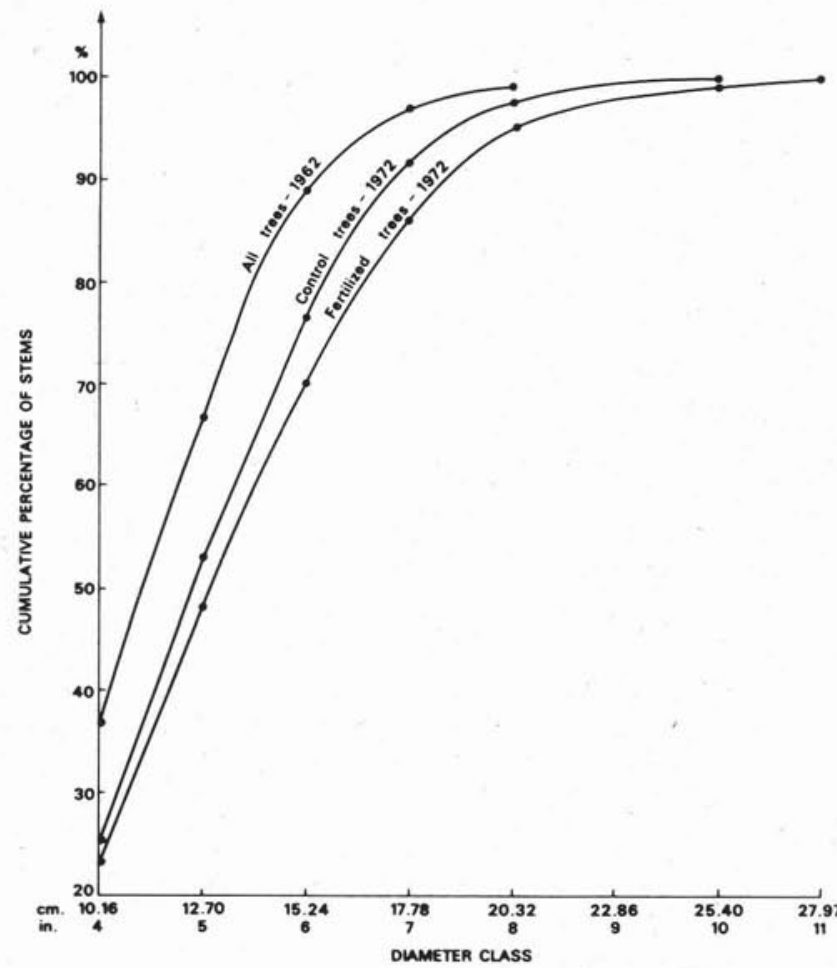

Figure 1. Cumulative frequency of the percentage of stems by diameter class for all trees in 1962 and for control and fertilized trees in 1972.
Table 1. Type of fertilizer and rates of application of fertilizer and of element

\begin{tabular}{|c|c|c|}
\hline \multirow[b]{2}{*}{ Fertilizer } & \multirow{2}{*}{\multicolumn{2}{|c|}{$\begin{array}{l}\text { Rates of application in } \mathrm{kg} / \mathrm{ha} \text { and } \\
\text { (lb/acre) } \\
\text { of fertilizer of element }\end{array}$}} \\
\hline & & \\
\hline $\begin{array}{l}\text { Urea }(45 \% \mathrm{~N}) \mathrm{N}_{1} \ldots \ldots \\
\text { Urea }(45 \% \mathrm{~N}) \mathrm{N}_{2} \ldots \ldots \\
\text { Sulphate of potash } \mathrm{K}_{1} \\
\text { Sulphate of potash } \mathrm{K}_{2} \\
\text { Magnesium sulphate }\end{array}$ & $\begin{array}{l}128(114) \\
256(228) \\
112(100) \\
224(200)\end{array}$ & $\begin{array}{rr}57 & (51)-\mathrm{N} \\
114 & (102)=\mathrm{N} \\
47 & (42)=\mathrm{K} \\
94 & (84)-\mathrm{K}\end{array}$ \\
\hline$(16 \% \mathrm{MgO}) \ldots \ldots$ & $224(200)$ & 21 (19) $-\mathrm{Mg}$ \\
\hline
\end{tabular}

Table 2. Adjusted values of basal area increment (1962-72) in square neters per hectare for all $\mathrm{N}$, $\mathrm{K}$ treatment combinations averaged over six replications

\begin{tabular}{lccccc}
\hline & \multicolumn{3}{c}{ Nitrogen } & Mean for K \\
\cline { 2 - 5 } & & $\mathrm{N}_{0}$ & $\mathrm{~N}_{1}$ & $\mathrm{~N}_{2}$ & \\
\multirow{4}{*}{ Potassium } & $\mathrm{K}_{0}$ & 8.43 & 8.62 & 8.45 & 8.49 \\
& $98.7^{+}$ & $9.87^{+}$ & $10.28^{++}$ & 9.97 \\
\cline { 2 - 4 } Mean for N & $\mathrm{K}_{2}$ & $10.59^{++}$ & $10.46^{++}$ & $10.97^{+++}$ & 10.67 \\
\cline { 2 - 5 } & 9.60 & 9.64 & 9.89 &
\end{tabular}

+ Significantly different from the control plots at $10 \%$ level.

+++ " " " ", , " , "

Average ffeect of $\mathrm{K}_{2}$ exceeds that of $\mathrm{K}_{0}$ by $26 \%$.

Note: All data were analysed in the English system and were converted to the metric system. 1 square meter $=10.7639$ square feet.

Table 3. Adjusted merchantable volume increment (196272 ) in cubic meters per hectare for all $\mathrm{N}, \mathrm{K}$ treatment combinations averaged over six replications

\begin{tabular}{llllll}
\hline & & \multicolumn{3}{c}{ Nitrogen } & Mean for K \\
\cline { 3 - 6 } & & \multicolumn{1}{c}{$\mathrm{N}_{0}$} & $\mathrm{~N}_{1}$ & $\mathrm{~N}_{2}$ & \\
\multirow{4}{*}{ Potassium } & $\mathrm{K}_{0}$ & 48.9 & 58.1 & $51.1^{1}$ & 52.4 \\
& $\mathrm{~K}_{1}$ & $61,5^{+++}$ & $66.5^{+++}$ & $67.9^{+++}$ & $65.0^{+++}$ \\
& $\mathrm{K}_{2}$ & $76.8^{+++}$ & $69.2^{+++}$ & $76.4^{+++}$ & $74.1^{+++}$ \\
\cline { 3 - 5 } Mean for N & & 62.3 & 64.2 & 65.0 &
\end{tabular}

${ }^{+++}$Significantly different from the control plots at $1 \%$ level. Mean for $\mathrm{K}_{1} \mathrm{~N}_{0}$ exceeds mean for $\mathrm{K}_{0} \mathrm{~N}_{0}$ by $26 \%$.

Mean for $\mathrm{K}_{2} \mathrm{~N}_{0}$ exceeds mean for $\mathrm{K}_{0} \mathrm{~N}_{0}$ by $57 \%$.

Note: All data were analysed in the English system and were converted to the metric system. 1 cunit/acre $=$ about 7 $\mathrm{m}^{3} / \mathrm{ha}$.

Table 4. Absolute growth data before and after fertilization (1962-1972)

\begin{tabular}{|c|c|c|c|c|c|c|c|c|c|c|c|}
\hline \multirow[b]{3}{*}{ Treatment } & \multirow{3}{*}{$\begin{array}{l}\text { Number of } \\
\text { trees/ha } \\
1972^{*}\end{array}$} & \multirow{2}{*}{\multicolumn{2}{|c|}{$\begin{array}{l}\text { Average } \\
\text { diameters } \\
(\mathrm{cm})\end{array}$}} & \multirow{2}{*}{\multicolumn{2}{|c|}{$\begin{array}{c}\text { Average } \\
\text { basal area } \\
\left(\mathbf{m}^{2} / \mathbf{h a}\right)\end{array}$}} & \multicolumn{4}{|c|}{$\begin{array}{c}\text { Average volumes } \\
\left(\mathbf{m}^{3} / \mathbf{h a}\right)\end{array}$} & \multicolumn{2}{|c|}{$\begin{array}{c}\text { Volume increase } \\
\left(\mathbf{m}^{3} / \mathbf{h a}\right)\end{array}$} \\
\hline & & & & & & \multicolumn{2}{|c|}{ total } & \multicolumn{2}{|c|}{ merchantable } & total & merch. \\
\hline & & 1962 & 1972 & 1962 & 1972 & 1962 & 1972 & 1962 & 1972 & \multicolumn{2}{|c|}{1962 to 1972} \\
\hline $\begin{array}{l}\text { Control...... } \\
\mathrm{N}_{2} \mathrm{~K}_{2} \ldots \ldots \ldots \\
\mathrm{K}_{2} \ldots \ldots \ldots \\
\mathrm{N}_{1} \ldots \ldots \ldots \\
\mathrm{N}_{1} \mathrm{~K}_{1} \ldots \ldots \ldots \\
\mathrm{K}_{1} \ldots \ldots \ldots \\
\mathrm{N}_{1} \mathrm{~K}_{2} \ldots \ldots \ldots \\
\mathrm{N}_{2} \mathrm{~K}_{1} \ldots \ldots \ldots \\
\mathrm{N}_{2} \ldots \ldots \ldots \\
\end{array}$ & $\begin{array}{l}2372 \\
2355 \\
2422 \\
2380 \\
2298 \\
2240 \\
2207 \\
2355 \\
2125\end{array}$ & $\begin{array}{l}12.47 \\
12.72 \\
12.78 \\
13.13 \\
13.03 \\
12.45 \\
12.12 \\
12.29 \\
12.45\end{array}$ & $\begin{array}{l}13.94 \\
14.76 \\
14.86 \\
14.78 \\
14.91 \\
14.22 \\
14.02 \\
14.15 \\
14.02\end{array}$ & $\begin{array}{l}31.15 \\
32.48 \\
33.78 \\
34.36 \\
31.47 \\
28.41 \\
26.87 \\
29.73 \\
27.99\end{array}$ & $\begin{array}{l}39.46 \\
43.97 \\
45.21 \\
43.97 \\
41.57 \\
37.69 \\
36.43 \\
39.82 \\
35.82\end{array}$ & $\begin{array}{l}168.2 \\
176.7 \\
180.7 \\
188.4 \\
169.3 \\
153.7 \\
140.3 \\
160.3 \\
155.4\end{array}$ & $\begin{array}{l}218.9 \\
254.4 \\
259.2 \\
249.7 \\
234.8 \\
217.0 \\
201.8 \\
222.5 \\
202.4\end{array}$ & $\begin{array}{l}123.2 \\
134.9 \\
136.9 \\
144.7 \\
127.6 \\
108.6 \\
108.1 \\
116.7 \\
114.6\end{array}$ & $\begin{array}{l}175.8 \\
213.3 \\
216.3 \\
207.6 \\
194.0 \\
172.5 \\
163.3 \\
182.2 \\
162.1\end{array}$ & $\begin{array}{l}50.8 \\
77.7 \\
78.6 \\
61.3 \\
65.5 \\
63.4 \\
61.5 \\
62.2 \\
47.0\end{array}$ & $\begin{array}{l}52.7 \\
78.5 \\
79.4 \\
62.8 \\
66.4 \\
63.9 \\
55.5 \\
65.5 \\
47.5\end{array}$ \\
\hline
\end{tabular}

Note: All data were recorded in the English system and were converted to the metric system. $1.54 \mathrm{~cm}=1 \mathrm{inch} \cdot 1 \mathrm{~m} 3 / \mathrm{ha}-14.291$ $\mathrm{ft}^{3} /$ acre.

*In 1962 the number of trees per hectare was approximately 2965 for each treatment. 
ning and at the end of the experiment was calculated using local volume tables. Volume increment was also adjusted for mortality (Table 3 ). Absolute growth data before and after fertilization are given per plot and per cubic meters per hectare (Table 4). Tree mortality was recorded for each diameter class (Figure 1).

\section{Results and discussion}

Results of growth response, 10 years after fertilization, are presented in four sections: the first one deals with adjusted basal increment; the second with adjusted volume increment; the third with absolute tree growth data before and after fertilization; and the last with the trend in diameter class distribution in 1962 and 1972.

\section{Basal area increment}

In 1962, 30 trees per sample plot were labelled for later measurements. In the fall of 1972, at the end of the experiment, the number of surviving sample trees varied considerably (Table 4). This variation in number of trees due to mortality obviously led to variations in basal area increment, not only between treatments, but also within treatments. These variations were adjusted by covariance analysis. The 1962 basal area was used to adjust the current growth increment figures. The analysis has been carried out on the adjusted values (Table 2).

Adjusted values of basal area increment (196272) on plots that received various levels of $K$ was significantly greater than that of control plots. The degree of significance varied from $1 \%$ to $10 \%$. The average affect of $\mathrm{K}_{2}$ alone exceeded that of $\mathrm{K}_{0}$ by $26 \%$, while a combination of $\mathrm{N}_{2} \mathrm{~K}_{2}$ exceeded the control plots by $30 \%$. The higher growth in basal area obtained with $\mathrm{N}_{2} \mathrm{~K}_{2}$ probably indicates some effect of nitrogen. However, comparisons made between nitrogen plots at equal application levels of $\mathrm{K}$ show that no practical differences exist when we consider that the L.S.D. (least significant difference) at the $10 \%$ probability level is 0.33 square meters. Soil and foliage analyses revealed potassium was the limiting growth factor in the Grand'Mère white spruce plantations (Truong dinh Phu and Gagnon 1975).

\section{Volume increment}

Response to treatments measured in terms of merchantable volume (Table 3) indicated similar trends to those found in the basal area increment results reported in Table 2. Again, the analysis of covariance was used to adjust differences in stocking existing at the start of the fertilization trial in 1962.

Nitrogen treatments had no apparent influence on merchantable volume increment 10 years after the fertilizer application, while the effect of $K$ is strongly in evidence (Table 3 ). The best adjusted treatment, $\mathrm{K}_{2}$ alone, compared with $\mathrm{N}_{0} \mathrm{~K}_{0}$ produced an extra $27.8 \mathrm{~m}^{3} /$ hectare $\left(400 \mathrm{ft}^{3} /\right.$ acre or 4 cunits / acre) of merchantable wood. Such a gain, 10 years after fertilization, is enough to arouse the enthu- siasm of any company forester, especially those at Grand'Mère where the plantations are so close to the pulp and paper mill.

\section{Growth data in 1962 and 1972}

The relative efficiency of different treatments is better illustrated when total and merchantable volumes at the beginning of the fertilization experiment are compared with those at the end of the trial along with the number of trees and diameter changes from 1962 to 1972 (Table 4). Averaged data shown in this table have not been adjusted to account for initial variation representing absolute mathematical averages.

The total number of trees per hectare declined about 22\% between 1962 and 1972 (2965 to 2306). Trees smaller than $10.16 \mathrm{~cm}$ (4 in.) accounted for $17 \%$ of the loss. During the fertilization experiment, mortality occurred mostly in the lower diameter classes. In these classes, $60 \%$ of the mortality was observed in the control plots and $50 \%$ in the fertilized plots. As mortality of trees in the lower classes may be due to many imponderable factors, it would be a speculative assumption to attribute lower mortality to fertilization. The $5 \%$ mortality in merchantable diameter classes was due to pathological conditions (Lavallée 1972; Ouellette et al. 1965), and also to a spruce budworm infestation which, since 1966, has been increasing in intensity. Tree pathological conditions did not change following fertilization (D. Lachance 1974, unpublished data). Defoliation percentage also had not been checked by fertilization (Y. Hardy 1974, typewritten report, Univ. Laval).

Before fertilization in 1962, half the plots to be fertilized had an average tree diameter of 12.12 $\mathrm{cm}$ (4.77 in.), and the other half had an average tree diameter of $13.13 \mathrm{~cm}$ (5.17 in.). The control plots with an average tree diameter of $12.47 \mathrm{~cm}$ (4.90 in.) stood in the middle. This indicates that, before fertilization, all plots were well selected with respect to tree diameter. In 1972, 10 years after fertilization, it is noticeable that the average tree diameters of all the fertilized plots exceed the average of the control plots. The results agree with basal area increment (Table 2), although in this last case values have been adjusted for initial variation.

Absolute total, as well as absolute merchantable, volume increments following fertilization are much higher for fertilized plots than for controls, if we take into account initial volumes in 1962. However, there is an exception for the $\mathrm{N}_{2}$ treatment where both total and merchantable volume increment are somewhat lower than the control. This exception is due to the $50 \%$ mortality recorded in sample plot no. 57. This plot was retained because at the beginning of the experiment it had the same number of trees as the other sample plots on similar sites. The extra merchantable wood obtained with $\mathrm{K}_{2}$ and $\mathrm{N}_{2} \mathrm{~K}_{2}$ treatments is worth thinking about when discussing the economic aspects of this fertilization trial. Absolute values of total and merchantable volume incre- 
ments for control plots of 50.8 and $52.7 \mathrm{~m}^{3} / \mathrm{ha}(725$ and $752 \mathrm{ft}^{3} /$ acre) in only 10 years, indicates the fast rate of growth of the plantations studied. The fast rate of growth of fertilized trees should continue since, 10 years after fertilization, differences in the fertility level of the top layer of surface-soil are still evident (Roberge 1975). Tree form, which was expected to increase the volume following fertilization, has not been significantly changed by the fertilizer treatments (S. Popovich, 1975, personal communication). For this reason, changes in tree form factor have not been considered in volume evaluation.

\section{Diameter class distribution 1962 and 1972}

Diameter class distribution before and after fertilization illustrates both the vigor of the plantations and the influence of fertilization on tree size (Fig. 1). In the fall of 1962, diameter class distribution of the control sample plots was identical to that of the plots to be fertilized; the curves of both distribution coincided. In the fall of 1972, after 10 growing seasons, the diameter classes of the control plots had changed considerably. The change is most evident in the $10.16 \mathrm{~cm}$ ( 4 in.) class as very few trees belonged to this diameter class in 1972. In the highest diameter class, the change is less evident due to the small number of trees in this class size in 1962 . Yet, $1 \%$ of all trees, or 19 trees moved from the $20.32 \mathrm{~cm}$ ( 8 in.) or lower classes into the $25.40 \mathrm{~cm}$ (10 in.) class. The influence of fertilization on diameter class distribution is more pronounced for diameter classes of $15 \mathrm{~cm}$ ( 6 in.) and over. Although the change in diameter class distribution between 1962 and 1972 for fertilized trees is not as marked as it is for non-fertilized trees, it indicates that the change was large enough to produce considerable greater volume increases in fertilized plots than in controls.

Extra absolute, as well as adjusted, volumes obtained with $\mathrm{K}_{2}$ treatment, the best treatment, are most interesting. Economic analysis indicates that the $\mathrm{K}_{2}$ treatment produced fertilizer grown wood at a cost of $\$ 2.36 / \mathrm{m}^{3}$ (\$6.72/cunit). Wood on the stump in these plantations is valued at $\$ 6.36 / \mathrm{m}^{3}$
$\$ 18.00$ /cunit), indicating that it is profitable to fertilize with potassium at appropriate rates as the plantations are only 50 -year-old and still developing.

\section{Acknowledgments}

The authors wish to thank Mr. Emil Koller of the Pulp and Paper Research Institute of Canada for providing statistical services. They also thank Mr. Truong dinh Phu of the Laurentian Forest Research Centre who kindly revised the statistical analyses and made the transformation from the English to the metric system.

\section{References}

Conway, J.M. 1960. Tree nutrient problems - Grand'Mère plantations. For. Dep., Consol. Pap. Corp. Ltd.

1964. On the rentability of the Grand-Mère plantations. Commun. C.P.P.A. Montreal, W.S1. No. 2321 (F-1).

Cunningham, G.C. 1953. Growth and development of coniferous plantations at Grand'Mère, P.Q. Can. Dep. Northern Affairs Nat. Res., Forest., Branch Silv. Res. Note No. 103.

Gagnon, J.D. and J. D. MacArthur. 1959. Ground vegetation as an index of site quality in white spruce plantations. Can. Dep. Northern Affairs Nat. Res., Forest. Branch Tech. Note 70 .

Gagnon, J.D. 1972. Grand'Mère plantations: an example for future reforestation. Can. Centre Rech Forest Laurentides, Ste-Foy, Qué. Rapp. Inf. Q-X-30. 27 p.

Lafond, A. 1958. Les déficiences en potassium et magnésium des plantations de Pinus strobus, Pinus resinosa et Picea glauca dans la Province de Québec. Fond. Rech. Forest., Univ. Laval Contrib. No. 1.

Lavallée, A. 1972. Etat pathologique d'une plantation d'épinette blanche après fertilisation à Grand'Mère. Can. Centre Forest. Laurentides, Rapp. Inf. Q-F-X-33.

Ouellette, G.B., J.M. Conway, et G. Bard. 1965. Fréquence et intensité du chancre cystosporéen dans les plantations d'épinette du Québec. Forest. Chron. 41(4): 444-453.

Paine, L.A. 1960. Studies in Forest Pathology XXII. Nutrient deficiencies and climatic factors causing low volume production and active deterioration in white spruce. Can. Dep. Agric., Forest Pub. 1067.

Roberge, M. R. 1975. La fertilité de I'horizon de surface du sol d'une plantation d'épinette blanche 10 ans après fertilisation. Unpub. rep. Can. Centre Rech. Forest. Laurentides, Ste-Foy, Qué.

Swan, H.S.D. 1962. The mineral nutrition of the Grand'Mère plantations. Res. Index, Pulp Pap. Res. Inst. Can. No. 131.

Truong dinh Phu and J.D. Gagnon. 1975. Nutrient-growth relationships in the Grand'Mère white spruce plantations before and after fertilization. Can. J. Forest. Res. 5:640-648. 